УДК 374.33

\title{
АНАЛИЗ ЗДОРОВЬЕСБЕРЕГАЮЩИХ ТЕХНОЛОГИЙ ПОСРЕДСТВОМ ИНТЕГРАЦИИ ДОПОЛНИТЕЛЬНОГО ОБРАЗОВАНИЯ
}

Попова Елена Викторовна

Симонова Ольга Ивановна

к.б.н., доценты

Березина Таисия Андреевна

Сартакова Анджела Юрьевна

ФГБОУ ВО Горно-Алтайский государственный университет

\begin{abstract}
Аннотация: Работа рассматривает проблему интеграции общеобразовательного процесса с внеучебной деятельностью детей и подростков, как одну из основных решений профилактики заболеваний у обучающихся. В период обучения в общеобразовательных организациях сохранить здоровье подрастающего поколения, проблема серьёзная и пока не разрешимая. Дополнительное образование способно внести весомый вклад в решении задач сохранения здоровья подрастающего поколения.

Ключевые слова: здоровьесбережение, дети, дополнительное образование, внеучебная деятельность, интеграция, пространство взаимодействия.
\end{abstract}

\section{ANALYSIS OF HEALTH-SAVING TECHNOLOGIES THROUGH INTEGRATION OF ADDITIONAL EDUCATION}

\begin{abstract}
The paper considers the problem of integrating the General education process with extracurricular activities of children and adolescents as one of the main solutions to prevent diseases in students. During the period of training in General education organizations to preserve the health of the younger generation, the problem is serious and not yet solvable. Additional education can make a significant contribution to solving the problems of preserving the health of the younger generation.

Key words: health care, children, additional education, extracurricular activities, integration, interaction space.
\end{abstract}


Здоровье - один из главных компонентов человеческого благополучия, счастья, одно из неотъемлемых прав человека, одно из условий успешного социального и экономического развития любой страны. Высокая информативность образования, перегрузки учащихся влекут за собой явление переутомления и всяческие его последствия, в том числе - ухудшение здоровья [3].

Как правило, в общеобразовательном процессе сохранить здоровье подрастающего поколения, проблема пока не разрешимая. Дополнительное образование в этом плане имеет более высокие шансы. Ведь в дополнительном образовании нет необходимости усваивать больше учебной информации в ограниченное время, что уже благоприятно сказывается на состоянии физического, психического здоровья детей и подростков. Кроме того, именно здесь, в дополнительном образовании, появляется реальная возможность реализовать цели и задачи здоровьесбережения детей.

В современное время, когда появляются новые стандарты образования, педагогические работники, должны рационально организовывать учебную и внеучебную деятельность детей и подростков, снижая чрезмерное функциональное напряжение и утомление, создавая условия для недопущения переутомления, чередуя труд и отдых.

Двигательная активность является важнейшим компонентом образа жизни и поведения подростка, оно определяется как социальноэкономическими условиями и уровнем культуры общества, так и организацией физического воспитания, а также индивидуально-типологическими особенностями высшей нервной деятельности, особенностями телосложения и функциональными особенностями и возможностями детей.

При этом проблема рациональной двигательной активности особое значение приобретает в период становления и совершенствования систем и функций организма, когда закладывается фундамент физической культуры личности и моторного потенциала человека [3]. Кроме того, уровень мелкой моторики без стимуляции физиологических функций, без физических упражнений и тренировок не развивается в достаточной мере [4].

В связи с этим, можно предположить, что существуют следующие основные проблемы и ошибки обучения общего и дополнительного образования навыкам физической культуры, которые должны формировать мотивацию к здоровому образу жизни. Поэтому, как правило, не рассматриваются индивидуально-психологические особенности детей и 
подростков; нарушается принцип свободного выбора ребенком внеурочной деятельности; не отработана координация занятости ребенка во внеучебное время; не учитывается уже состоявшийся выбор ребенком занятий в учреждениях дополнительного образования (УДО) или учреждениях спорта ит.д.

На наш взгляд сложность заключается ещё и в том, что не определены условия финансирования внеурочной деятельности между школой и УДО.

И как вследствие, все эти ошибки выливаются на самое ценное, на здоровье детей и подростков, что приводит к нарушению здоровьесберегающих технологий.

Из вышесказанного, надлежит усилить совместную работу педагогов с родителями по проведению спортивных соревнований, дней здоровья, занятий по профилактике вредных привычек и т.п.

Необходимо соблюдение основных гигиенических норм и требований к организации и объёму учебной и внеучебной нагрузки (выполнение домашних заданий, занятий в кружках и спортивных секциях) учащихся на всех этапах обучения. Целесообразно использование методов обучения, адекватных возрастным и морфофизиологическим возможностям и особенностям детей и подростков; введение любых инноваций в учебный процесс только под контролем специалистов; строгое соблюдение всех требований к использованию технических средств обучения, в том числе компьютеров; работа по индивидуальным программам на всех уровнях образования, и в первую очередь детьми с ослабленным здоровьем и детьми с ограниченными возможностями здоровья, посещающими специальные медицинские группы под строгим контролем медицинских работников; организация активных школьных перемен, физкультминуток на уроках, способствующих эмоциональной разгрузке и повышению двигательной деятельности[2].

Вместе с тем, здоровьесберегающая образовательная среда имеет принципиальное значение для формирования гармонично развитой личности. Только тогда, когда в образовательных учреждениях будет создана такая среда (климат здоровья, культура доверия, личностное созидание), возможны полноценное сохранение и укрепление здоровья, формирование культуры здоровья, усвоение ее духовно-нравственных, эстетических, физических компонентов [1].

Таким образом, новые образовательные стандарты в полной мере могут быть реализованы только в процессе интеграции дополнительного и общеобразовательного процессов. 
Современное дополнительное образование пока не отвечает этим требованиям, но перспективы развития есть, разумнее не разрушать его, а дополнять и сохранять лучшее и развивать в рамках современных требований.

\section{Список литературы}

1. Дереклеева Н.И. Справочник классного руководителя: 1 - 4 классы. 3-е изд., перераб. и доп. - М.: ВАКО, -2008. - 352 с.

2. Ковалько В.И. Здоровьесберегающие технологии в начальной школе. M.: BAKO, - 2004. - 296 c.

3. Popova E., Makhalin A., Zabolotnaya I., Simonova O., Motor activity analysis by children Gorno-Altaisk aged 6-7 yars. // Национальные программы формирования здорового образа жизни: материалы Междунар. науч.-практ. конгресса: в 2 т. (г. Москва, 27-29 мая 2014 г.). - Т. 1. 2014. - С. 126- 128

4. Popova E., Simonova O., Makhalin A., Zabolotnaya I., Motor skills in preschool children // Вестник Московского университета. Серия 23: Антропология. - 2014. - № 3. - С. 39-40.

(C) Е.В. Попова, О.И. Симонова, Березина Т.А., Сартакова А.Ю., 2020 